\title{
Anthropogenic soil and settlement organisation in the Bolivian Amazon
}

Mark Robinson $^{1 *}$, Carla Jaimes Betancourt ${ }^{2}$, Sarah Elliott ${ }^{3}$, S. Yoshi Maezumi ${ }^{4}$, Lautaro Hilbert ${ }^{5}$, Daiana Alves ${ }^{6}$, Jonas Gregorio de Souza ${ }^{7}$, José Iriarte ${ }^{1}$

1 Department of Archaeology, University of Exeter, Exeter EX4 4QE, UK

2 Department for the Anthropology of the Americas, University of Bonn, Bonn, 53111, Germany

3 Department of Archaeology, Anthropology and Forensic Science, Bournemouth University, Poole, BH12 5BB, UK

4 Department of Ecosystem and Landscape Dynamics, University of Amsterdam, $1090 \mathrm{GE}$

Amsterdam, The Netherlands

5 Museum of Archaeology and Ethnology, University of São Paulo, São Paulo, SP 05508-070, Brazil

6 Department of Anthropology, Federal University of Pará, Belém - PA, 66075-110, Brazil

7 Department of Humanities, University Pompeu Fabra, 08002, Barcelona, Spain

*corresponding author: markrobinson.uk@gmail.com

\section{KEY WORDS}

Laguna Versalles, Amazon Archaeology, Amazonian Dark Earth, Amazonian Brown Earth, Terra Preta, Zanja

\begin{abstract}
Anthropogenic soils known as Amazonian Dark Earths have long been known as a key component of subsistence systems for various pre-Columbian Amazonian populations. Often treated as a single category, ADE systems consist of two broad anthrosols (human-modified soils); the darker ADE (traditionally known as terra preta) and a lighter brown Amazonian Brown Earth (ABE, traditionally known as terra mulata). Data on the characteristics and spatial distribution of these anthrosols is severely lacking. Transects of soil test pits at the Triunfo and Versalles archaeological sites in the Iténez Forest, in the Bolivian Amazon, show variability in the distribution of soil types, revealing aspects of settlement organisation and resource management. Geochemical, isotopic, and archaeobotanical data from an $\mathrm{ADE}, \mathrm{ABE}$ and control soil profile from the Triunfo site, established ca. cal $500 \mathrm{BCE}$, characterise the two anthrosols as distinct components of a polyculture agroforestry subsistence system that combines anthropogenic soil fertilisation, closed-canopy forest enrichment, limited forest clearance for crop cultivation and low-severity fire management.
\end{abstract}

\subsection{Introduction}


The savannas and forested regions of southwestern Amazonia evidence some of the most important cultural developments in the Amazon. Alongside a mosaic of languages, cultures, and earthwork constructions, the region is a centre of crop genetic diversity (Clement, 1999) and plant domestication (Blatrix et al., 2018; Capriles et al., 2019; Clement et al., 2016; Hilbert et al., 2017; Lombardo et al., 2020; Piperno and Pearsall, 1998). Coinciding with some of the earliest cultivars, the forested region records the earliest development of the anthropogenically created Amazonian Dark Earths (ADE) (Watling et al., 2018). Anthrosols (human-modified soil) are a distinctive feature of pre-Columbian subsistence that have been documented across Amazonia. The darker soils, with high nutrient values and large stocks of stable soil organic matter, markedly contrast in colour and fertility from the natural, nutrient-poor tropical soils. These anthrosols have been shown to support nutrient demanding crops and have provided evidence of landscape-scale transformations of Amazonia by humans that have a lasting impact on forest composition and biodiversity (Glaser and Birk, 2012; Heckenberger and Neves, 2009; Maezumi et al., 2018; McMichael et al., 2014; Woods et al., 2009). Despite these important subsistence innovations, Amazonian food production systems are still poorly understood, and notwithstanding decades of scholarly attention, there are still many questions to be answered regarding the complexity and holistic nature of ADE systems.

Although ADEs are commonly treated as a single category of anthrosol, researchers, indigenous communities, and local farmers have long recognised two divisions: terra preta or Amazonian Dark Earth (hereafter ADE) and terra mulata or Amazonian Brown Earth (hereafter ABE). We follow Alves (2017:25) in rejecting the nomenclature terra mulata as the term has a "cruel origin" and "pejorative meaning of miscegenation and impurity", refering to "interethnic breeding that resulted largely from rapes during the 354 years (1534 to 1888) of black slavery in Brazil."

ADEs have been far more intensively studied than ABEs, and often research does not consider ABE soils in research design nor make an attempt to positively or negatively document their presence. Generally, ADE formation is seen as the accumulation of midden refuse around permanent habitation sites, incorporating the decomposition of organic waste (food waste, plant-based construction 
materials, excrement, domestic fires, etc.) and an abundance of cultural artefacts, such as ceramics, and faunal bones (e.g. Arroyo-Kalin, 2014; Erickson, 2004; Glaser and Birk, 2012; Kern, 1989; Woods, 1999, 2009). ADE are characterised by high content of organic matter and charcoal, higher pH values and greater concentrations of $\mathrm{P}, \mathrm{Ca}$, and Mg (Glaser and Woods, 2004; Lehmann et al., 2004; Teixeira, 2010; Woods, 2009). Composition and thickness vary dependent on the specific intensity, duration, and distribution of human activities at the location (Kern, 2017). Thickness varies from $15-370 \mathrm{~cm}$ and charcoal content has been shown to be four times greater than neighbouring soil, reaching as much as 70 times higher in the upper soil profile (Glaser et al., 2001). Pyrogenic carbon contributes to stable soil organic matter (SOM), with high nutrient retention capacity such that the colour and higher fertility of ADE may persist in the environment for centuries after human abandonment of the landscape and cessation of anthropic inputs (Woods, 2009). ADE and their increased fertility are likely an unintentional by-product of habitation, although Amazonian farmers often took advantage of them for cultivation, either as home-gardens or repurposed as agricultural plots if the area no longer served a domestic function.

In contrast $\mathrm{ABE}$ are the result of long-term soil-management practices for agriculture, such as mulching and infield burning (Denevan, 1996; McCann et al., 2001; Paz-Rivera and Putz, 2009; Woods et al., 2000). A critical aspect of ABE formation seems to have been a burning practice that left intact charcoal that, unlike ashes, is not degradable. This incomplete 'slash and char', 'cool' burning contrasts with today's prevailing practise of slash and burn, in which combustion is hot and complete after a long period of drying (Denevan, 2004). Micromorphology studies by Arroyo-Kalin (2010) in an ABE show evidence of a clear truncation between a well-preserved buried A horizon and its underlying B horizon, indicating some form of scraping, raking and churning. Strong magnetic susceptibility recorded in ABEs indicate that iron in the soil became magnetised through in-situ heating, suggesting management practices involving near-surface burning of organic matter (ArroyoKalin, 2014). Costa et al. (2013) showed that ABE locations exhibit signs of successive burning of organic matter and transformation of minerals (maghemite to goethite) and analysis of ABE around 
Santarem by Woods and McCann (1999) evidenced slightly higher total carbon but lower P and Ca values, suggesting intensive burning of purposely added mulch.

$\mathrm{ABE}$ often surround the periphery of $\mathrm{ADE}$ patches with a transitional gradation between the two (Fraser et al., 2011), which likely reflects changes in the intensity and type of activity; however, the two soil types are distinct in their genesis, location, and archaeological features and artefactual content. ABEs are generally more extensive, lighter in colour (dark brown to brown or brownishgrey), shallower, and have an A-horizon with a high organic matter and charcoal content. As well as the lighter colour, archaeological features and cultural materials (e.g. ceramics) are typically absent from $\mathrm{ABE}$ contexts, as such, they are seldom recognised as archaeological sites and less attention has been paid to their study.

ADEs have been documented for multiple Amazonian cultures across all ecoregions of Amazonia (Figure 1) (Kern et al., 2003) and spatial modelling using the biogeographical characteristics of known ADE predict many more sites across the unexplored tropical forest (de Souza et al., 2018; McMichael et al., 2014). They have predominately been documented on strategically advantageous topographic positions, such as plateaus overlooking rivers and streams (Heckenberger, 2008; Kern, 2003; Schaan, 2012; Stenborg, 2012) and along major rivers. Mounting evidence; however, records the presence of ADE sites in interfluvial areas as research project explore more areas away from the major rivers (de Souza, 2018; Franco-Moraes, 2019; Gonda, 2018; Heckenberger, 2008; Levis et al., 2012, 2014; Paz-Rivera, 2009; Schaan, 2012), suggesting current predictive models underestimate the extent of ADE sites across Amazonia. Like ADE, when reported, ABE have been documented from the western to eastern Amazon (Kern et al., 2017). They have been reported in various locations in the Lower Amazon (Alves, 2017; Costa et al., 2013; Sombroek et al., 2002; Stenborg, 2016; Troufflard and Alves, 2019; Woods and McCann, 1999), Central Amazon (Arroyo-Kalin, 2010; Gonda, 2018), Upper Tapajos (de Souza et al., 2018; Iriarte et al., in press), southwest Amazonia (this paper; Quintero-Vallejos et al., 2015), and the Colombian Amazon (Mora et al., 1991). As a pan-Amazonian 
phenomenon they are heterogeneous and not always present, even when ADE is present (e.g. Alho et al., 2019).

Although many anthrosol sites have been identified (Figure 1) and there has been great developments in understanding their formation processes, little is known about the localised site-based distribution and size of ADEs. There is a particular dearth of data regarding the spatial distribution and relationship between ADE and the lighter coloured ABE. Many accounts record the presence of ADE without determining their spatial extent nor distinguishing whether, and to what extent $\mathrm{ABE}$ is present. While this is understandable considering the physical limitations of effective survey in dense tropical forests, unfortunately, it also means that key components of the regional subsistence system and its wider cultural implications for community organisation and resource management remain little understood.

Recent integrated archaeobotanical and paleoecological research has revealed ADE and ABE to be distinct components of a sustainable polyculture agroforestry system that combines anthropogenic soil fertilisation, closed-canopy forest enrichment, limited forest clearance for crop cultivation and lowseverity fire management (de Souza et al. 2019; Iriarte et al. 2020; Maezumi et al., 2018). ADE and ABE soils are utilised differently as part of a holistic settlement and subsistence system. A greater understanding of the distinct properties and distribution of these soils can therefore reveal key aspects of pre-Columbian community organisation and subsistence.

Here we report the first survey and test excavations around Laguna Versalles in the Iténez Forest, on the Bolivia/Brazil border (Figure 1). We report the presence of ADE from ca. cal $500 \mathrm{BCE}$ and conduct a preliminary test pitting methodology to assess the distribution of ADE and ABE across two sites, Versalles and Triunfo. Geochemical, isotopic and archaeobotanical analyses show distinct profiles of ADE, ABE, and natural control soils at Triunfo, and the two sites display different distribution patterns of anthropogenic soil, revealing a spatial variability to ADE systems that is often overlooked. Preliminary excavations show that the two sites and their soil resources were later 
enclosed within a bounded and fortified landscape, with post holes inside a ditched boundary earthwork suggesting the addition of a palisade. These data document an unexplored region of Amazonia and provide insight into the creation and spatial heterogeneity of ADE systems with implications for understanding pre-Colombian settlement patterns and resource management practices.

\subsection{Geographical and Archaeological Context}

The Iténez Forest Reserve (IFR) is a $\sim 5,000 \mathrm{sq}$. km tract of forest located on the southwestern extent of the Amazon forest, bordered by the savannas of the Llanos de Mojos to the south (Langstroth, 2012; Mayle et al., 2007; Olson et al., 2001). The IFR is located in the northeast of the Bolivian Department of Beni, between the municipalities of Magdalena and Baures of the Iténez Province. The reserve is situated on the Bolivia/Brazil border, which is demarcated by the Iténez River (known as the Guapore in Brazil). The river is navigable year-round and is currently the major artery for local communities for trade and transport. Today, only a few small communities live around the edges of the forest reserve and much of the forest is largely undisturbed. On the Bolivian bank of the river, the Itonama indigenous community of Versalles, comprising 33 families, is currently only accessible by boat or light aircraft using a grass runway cut into the forest. A gentle slope gives access to the river at the eastern end of the village, with steep banks (3-7 m) along the rest of the river. The modern village is built on a pre-Columbian settlement, evident by pre-Columbian anthrosols, abundant ceramics, and a long, banked ditch, known in the region as a zanja. Laguna Versalles, four kilometers southwest of the village, is a 5.7 by $4.4 \mathrm{~km}$ closed-basin freshwater lake. The lake is bounded by terra firme forest, with a seasonally flooded savanna on the southern side. No archaeological research has been conducted in the interior of the reserve to assess potential pre-Columbian activity.

Along the Iténez River archaeological research has been very limited. Erland von Nordenskiöld opportunistically collected ceramics from the ground surface at a number of locations during boat trips along the Iténez in 1908 and 1909 (Jaimes Betancourt, 2011; Nordenskiöld, 1923, 1924). Excavations by Becker Donner (1956) along the entire Iténez River also collected ceramics. Jaimes 
Betancourt's museum analysis of the ceramic material identified a large diversity in styles amongst locations, suggesting cultural or temporal heterogeneity.

On the southern boundary of IFR, large-scale excavations and LiDAR data have revealed a system of ditches over an area of approximately $200 \mathrm{~km}^{2}$ (Prümers, 2014; Prümers and Jaimes Betancourt, 2014).The data show that these ditched systems are located on small plateaus overlooking intermittent streams, some of which enclose areas greater than 200 ha on the high banks of major rivers. ADE is limited to the interior of the ring ditches. These sites are part of the Ring Ditch Region cultural area of the northeast sector of the Llanos de Mojos (Lombardo et al., 2011, 2015). Three ceramic phases have been defined for this cultural area based on excavation at the Jasiaquiri site, consisting of the Jasiaquiri Phase (cal CE 350 - 500), Equibeje Phase (cal CE. 500 - 800) and Irobi Phase (cal CE 1200 - 1500) (Prümers and Jaimes Betancourt, 2017, Jaimes Betancourt, 2016). In this region, habitation sites occur as circular ditched enclosures on the non-flooded forest islands that are larger than $1 \mathrm{~km}^{2}$, likely corresponding to the fortified villages described in historical accounts (Eder, [1772] 1985). The ditches exhibit diverse sizes and shapes, including octagons, hexagons, squares, rectangles, "D" shapes, circles and ovals, as well as irregular shapes (Erickson, 2000, 2008, 2009, 2010). Ditched enclosures are often several meters deep, exhibiting steep-sided walls, with some incorporating double ditches. The sites contain shallow ADE components (Hastik et al., 2013) and multiple burials (Prümers, 2014; Prümers et al., 2006). Paleoecological research in this region record the early presence of maize (Zea mays) around cal CE 1 and points to anthropogenic burning from ca. $500 \mathrm{cal}$ BCE (Carson et al., 2014). Archaeobotanical analysis suggests maize was an important component of diet at Bella Vista, with manioc (Manihot esculenta) also identified (Dickau et al., 2012).

\subsection{Methods}

The research team first visited the area in 2016 on a paleoecological expedition to core Laguna Versalles. During the trip the team became aware of the presence of pre-Columbian activity around the lake and Versalles village. An archaeological focused expedition returned in 2017 to undertake a four-week excavation. As an exploratory archaeological project, the research design focused on 
preliminary testing to recover basic cultural and chronological information, including survey and test pit excavations. The presence of ADE presented the opportunity to assess the distribution of anthropogenic soils across the sites.

Here we report on survey, test excavations and soil test pits. Archaeological excavations were focused on contexts around the modern village of Versalles and at Triunfo on the southwest shore of Laguna Versalles. Test excavations were conducted in Versalles and Triunfo to establish site chronology, recover cultural material, and assess site formation history. A series of 80 soil profiles were recorded in transects across Versalles (57) and Triunfo (23) to establish the distribution and depth of anthrosols. A post hole digger was used to quickly and efficiently dig to depths of pre-ADE soil. Depths of changes in soil texture and colour were recorded in the field using a Munsell colour chart. Two transects were sampled at Versalles, one running parallel and one perpendicular to the river. One transect running perpendicular from the lake was sampled at Triunfo. Three expanded soil test pits were excavated for archaeobotanical, geochemical and isotopic sampling at Triunfo, representing an $\mathrm{ADE}, \mathrm{ABE}$ and natural/control. The $50 \times 50 \mathrm{~cm}$ pits were sampled in $5 \mathrm{~cm}$ increments to preanthropogenic soils, or an arbitrary $75 \mathrm{~cm}$ depth in the case of the control profile. Soil samples were analysed for a suite of geochemical elements, focusing on fertility indicators. Analysis was conducted by NRM Laboratories, UK. The complete dataset is presented in the SI. Data precision is $\mathrm{pH} \pm 0.2$, Total $\mathrm{C}, \mathrm{N} \pm 10 \%$, Total metals $\pm 15 \%$, Exchangeable metals $\pm 20 \%$, LOI $\pm 10 \%$. Each $5 \mathrm{~cm}$ bulk sample was also assessed for $\delta^{13} \mathrm{C}$ to assess flora inputs into soil formation. Isotopic analysis was conducted by The Cornell Isotope Laboratory (COIL) on a Thermo Delta V isotope ratio mass spectrometer (IRMS) interfaced to a NC2500 elemental analyser. Repeat analysis of an in-house standard demonstrated a precision of $0.17 \%$ in $\delta^{13} \mathrm{C}$ (1 S.D.). The organic component of soil retains a signature of the photosynthetic pathway employed by the decomposed vegetation that contribute to its creation. This signature can be isotopically tested, with distinct $\delta^{13} \mathrm{C}$ results for $\mathrm{C}_{3}$ (tree) versus $\mathrm{C}_{4}$ (grass, including maize) vegetation cover. Plants following the $\mathrm{C}_{3}$ pathway have $\delta^{13} \mathrm{C}$ values ranging from -32 to $-22 \%$. $\mathrm{C}_{4}$ plant $\delta^{13} \mathrm{C}$ values range between -21 and -9\%o (Dümig et al., 2008). Archaeobotanical analysis of the samples (phytolith and macrocharcoal) was conducted following 
standard procedures (see Maezumi et al. 2018). Macrocharcoal was counted as particles $/ \mathrm{cm}^{3}$ samples. Full achaeobotanical analysis is presented elsewhere (Iriarte et al. 2020), with key results discussed here.

\section{Results}

\subsection{Survey}

Survey around Versalles village identified a wide dispersal of surficial ceramics and a range in colour of surface $\mathrm{ADE}$ and $\mathrm{ABE}$. The site boundaries are delimited by the river to the north, a low-lying wetland to the east, and a zanja to the west that curves round to the south. The zanja is composed of a ditch with a mounded bank on the village side of the ditch. Away from the river, the $615 \mathrm{~m}$ zanja curves around the edge of the ancient settlement, before it diminishes on the south side of the village. Construction of the runway appears to have levelled the terminus of the zanja. A cut through the natural levee by the river on the other side of the runway corresponds to the expected continuation of the feature. The anthropogenically enhanced levee rises ca. $3 \mathrm{~m}$ above the river and $1 \mathrm{~m}$ above the interior land surface. Within the large gap between the end of the zanja and the wetland to the east, the site boundary is solely marked by the presence of anthropogenic soils.

Pedestrian survey around Laguna Versalles was hampered by thick, scrub forest, making progress slow and reducing visibility at times to just a few meters. The seasonally flooded savanna to the south of the lake was partially flooded and was not surveyed. The eastern side of the lake is also seasonally flooded for $800 \mathrm{~m}$ from the lake shore. Three areas of concentrated past activity were identified around the lake. Noria, $1 \mathrm{~km}$ to the east beyond the flooded area, displayed ADE soils and surficial ceramics, but was not explored beyond a brief pedestrian survey and a soil test pit to assess the ADE context. Escondido, on the northwest corner of the lake has patches of darker soil and limited ceramics but was not explored further during the limited field season. Triunfo, on the southwest shore of the lake, bordering the seasonally flooded savanna, contains ADEs, a zanja, and an elliptical double ring ditch. There are patches of distinct vegetation at Triunfo, including discreet areas dominated by 
Arecaceae (palm; predominantly Attalea sp.) and Theobroma cacao (chocolate), which in other areas of Amazonia are closely associated with intense past activity (Balée 2013). As with Versalles, the site boundary at Triunfo is marked by natural and archaeological features. Laguna Versalles bounds the east and the seasonally flooded savanna forms the southeastern boundary. A zanja marks the western boundary and a double ring ditch is located at the northern extent of the site. The ring ditch is composed of a concentric elliptical double ditch. The outer ditch measures 185 x $215 \mathrm{~m}$ and up to four meters depth. The inner ditch measures 112 x $135 \mathrm{~m}$, and up to $1.5 \mathrm{~m}$ depth. There are four entryways to the enclosure, broadly aligned with the cardinal directions. Each entry provides a cut through the inner and outer mounded banks and creates bridges across the two ditches. The interior "plaza" does not include any earthwork architecture.

Assessment of satellite imagery (aerial photography - Google Earth, Zoom Earth- and LANDSAT) shows a distinct colouration and texture to the closed canopy vegetation (Figure 2), which aligns with distribution of archaeological features and anthropogenic soils at Triunfo and Versalles. The zanjas at both Triunfo and Versalles mark the site boundaries and enclose the anthrosols. Noria site also displays the same distinct vegetation pattern, although the spatial extent of the site has not been ground-truthed. Ground survey revealed that the understory vegetation within the site boundaries is particularly dense with extensive lianas and ground cover. Just beyond the site boundary the understory vegetation is more open, with fewer lianas and less understory vegetation.

\subsection{Excavations}

Excavation in an $\mathrm{ABE}$ at Versalles (excavation unit T62) uncovered a cached ceramic dish associated with the establishment of the anthropogenic soil. An AMS date on charcoal associated with the feature dates to $537-265 \mathrm{cal} \mathrm{BCE}\left(2380 \pm 30{ }^{14} \mathrm{C} \mathrm{BP}\right)$. This occupation timing matches the earliest evidence of humans around the southern edge of Iténez as evidenced by anthropogenic burning (Carson et al. 2015). A trench excavation across the profile of the zanja at Versalles revealed two construction phases (Figure 3). Two post holes were discovered on the western side of the ditch interior (away from the site core), associated with the second construction phase. Charcoal from the 
base of the earliest ditch cut provided a date of cal CE $1298-1399\left(660 \pm 30{ }^{14} \mathrm{C} \mathrm{BP}\right)$, with the second construction phase (and post holes) dating to cal CE $1628-1803\left(260 \pm 30{ }^{14} \mathrm{C} \mathrm{BP}\right)$. Test excavations in the interior of the double ring ditch at Triunfo reveal the presence of black ADE. Charcoal from fill material in the earliest phase dates to cal CE $1454-1626\left(400 \pm 30{ }^{14} \mathrm{C} \mathrm{BP}\right)$.

\subsection{Soil Test Pits}

The difference in the distribution of anthropogenic soils at Triunfo and Versalles demonstrate a spatial heterogeneity of ADE systems. At Versalles, the soil profiles transition back and forth between ADE and ABE across both transects (Figure 4). The distribution of ADE at Triunfo follows a more linear gradient (Figure 5). The darkest ADE are closest to the lake, transitioning to lighter brown ABE further inland, before natural soil profiles are encountered close to and beyond the bounding zanja. Carbon dating of the humin fraction from bulk soil at $95-100 \mathrm{~cm}$, marking the start of ADE at Triunfo, provides a date of $385-207 \mathrm{cal} \mathrm{BCE}\left(2270 \pm 30{ }^{14} \mathrm{C} \mathrm{BP}\right)$. The ADE at Versalles is estimated to cover 8 ha in total, encompassed within 62 ha of ABE. In contrast to Versalles, ADE covering an estimated 30 ha, extends over $400 \mathrm{~m}$ from the lakeshore at Triunfo, transitioning to 100 ha of lighter brown ABE up to the bounding zanja ditch.

\subsection{Geochemistry}

The soil test pits selected for geochemical, isotopic and archaeobotanical analysis (Figure 6) were sampled to depths of $75 \mathrm{~cm}$ in the control (202 cal BCE - CE 15 [2120 $\left.\left.\pm 30{ }^{14} \mathrm{C} \mathrm{BP}\right]\right), 75 \mathrm{~cm}$ in the $\mathrm{ABE}$ (cal BCE 1527-1323 [3220 $\left.\pm 30{ }^{14} \mathrm{C} \mathrm{BP}\right]$ ), and $110 \mathrm{~cm}$ in the ADE. AMS dates of the humin component of soil in the ADE were obtained from 70-75 cm (cal CE 140-356 [1820 $\left.\left.\pm 30{ }^{14} \mathrm{C} \mathrm{BP}\right]\right)$, $45-50 \mathrm{~cm}$ ( $\left.\mathrm{cal} \mathrm{CE} 684-881\left[1280 \pm 30{ }^{14} \mathrm{C} \mathrm{BP}\right]\right)$ and $10-15 \mathrm{~cm}$ (cal CE $\left.1803-\left[140 \pm 30{ }^{14} \mathrm{C} \mathrm{BP}\right]\right)$. The control is characterised by a mix of sandy loam, loamy sand, and sandy clay loam (see supplementary information for full dataset). The ABE generally transitions from a sandy loam to a loamy sand. The ADE transitions from a sandy loam to a sandy clay loam. Geochemical analysis of the Triunfo ADE agrees with findings for ADE reported across Amazonia, showing less acidity, increased fertility and a higher ability to hold nutrients (Arroyo-Kalin et al., 2008; Costa and Kern, 2013; Glaser, 2007; 
Glaser and Birk 2012; Glaser et al., 2001; Lehmann et al., 2003; Sombroek, 1966; Woods and McCann, 1999). Within the ADE $\mathrm{pH}$ ranges between 6.1 and 6.8. In the ABE $\mathrm{pH}$ ranges between 4.8 and 6.1. The control $\mathrm{pH}$ ranges from 3.8 to 4.8. Elevated $\mathrm{pH}$ levels elsewhere have been attributed to the contributions of charcoal and ash (Woods and McCann, 1999). Commonly reported elements, including $\mathrm{P}, \mathrm{N}, \mathrm{Ca}, \mathrm{Mg}$, and $\mathrm{Zn}$ are up to $130 \mathrm{x}$ higher in the $\mathrm{ADE}$ than the control profile. The ABE profile shows elevated fertility indicators, but to a far lesser degree than the ADE. The general trend shows a rapid and continued increase of geochemical values in the ADE from the lower to upper profile as the anthrosol is developed. A more gradual increase occurs in the ABE. The control displays minimal geochemical variability throughout its profile. The top $10 \mathrm{~cm}$, encompassing the modern humus and extensive root disturbance, is enriched in most elements in each profile. These values are excluded in the following report and discussion as they more closely reflect modern vegetation and atmospheric inputs, rather than factors controlling pre-Columbian pedogenesis.

Total Nitrogen, Copper, Zinc, Barium, Calcium, Magnesium, Manganese, Phosphorus, Potassium, Carbon, Strontium, as well as exchangeable Calcium, exchangeable Magnesium, and Cation Exchange Capacity all show elevated values in the anthropogenic soils compared to the control. Cation Exchange Capacity, measuring the capacity to hold nutrients and prevent nutrient leaching, records an increase from 4.7 to $17.7 \mathrm{meq} / 100 \mathrm{~g}$ in the $\mathrm{ADE}, 3.8$ to $7 \mathrm{meq} / 100 \mathrm{~g}$ in the $\mathrm{ABE}$, and 3.2 to $4.4 \mathrm{meq} / 100 \mathrm{~g}$ in the control. Total $\mathrm{N}$ ranges between 0.04 to $0.07 \mathrm{mg} / \mathrm{kg}$ in the control sample. Total $\mathrm{N}$ in the $\mathrm{ADE}$ and $\mathrm{ABE}$ profiles rise from 0.03 to $0.23 \mathrm{mg} / \mathrm{kg}$, and 0.03 to $0.13 \mathrm{mg} / \mathrm{kg}$, respectively, as the anthropogenic soils develop. Total P ranges are, 88 to $163 \mathrm{mg} / \mathrm{kg}$ in the control, 236 to $377 \mathrm{mg} / \mathrm{kg}$ in the ABE, and 478 to $2835 \mathrm{mg} / \mathrm{kg}$ in the ADE. The highest total P values of the ADE are 17 times that of the control. As an essential plant nutrient, the relatively low increase of Total P in the ABE compared to the ADE is of particular interest and is potentially indicative of the land use and demand for high fertility in each soil system. 
While most of the elevated elements in the anthropogenic soils display continuous increases throughout the profile, select elements reach a plateau or begin to decline in the upper $30 \mathrm{~cm}$, likely reflecting the loss or change of anthropogenic inputs on the post-abandonment landscape. Total $\mathrm{P}$ in the ADE rises from 478 to a peak of $2835 \mathrm{mg} / \mathrm{kg}$ at $22.5 \mathrm{~cm}$ depth, before values begin to fall. Copper reaches a peak of $15.5 \mathrm{mg} / \mathrm{kg}$ at $32.5 \mathrm{~cm}$ before levelling off in the upper profile to a mean of 14 $\mathrm{mg} / \mathrm{kg}$. Potassium rises from $60 \mathrm{mg} / \mathrm{kg}$ in the pre-ADE levels of the profile to a peak of $209 \mathrm{mg} / \mathrm{kg}$ at $17.5 \mathrm{~cm}$, before dropping to a mean of $168 \mathrm{mg} / \mathrm{kg}$ in the upper strata. Manganese and Barium only see drops in the upper 5 and $10 \mathrm{~cm}$, respectively, suggesting these elements are not entering the soil through the breakdown of new organic matter (humus).

The ADE has lower concentration of organic matter than the ABE and control profiles. LOI results range between 2.7 and $6.8 \% \mathrm{w} / \mathrm{w}$ in the $\mathrm{ADE}$, compared to 8.1 to $9.9 \% \mathrm{w} / \mathrm{w}$ in the control profile. The highest organic matter content is found in the $\mathrm{ABE}$, with a range of 8.0 to $12.2 \% \mathrm{w} / \mathrm{w}$. Reported soil analysis from sites in Brazil also document higher concentrations of organic matter in ABE over ADE (Woods and McCann, 1999). Woods and McCann (2009) conclude that ABE lacks inputs from habitation waste, but benefits from long-term soil management practices, likely including mulching and burning.

Total Sodium values are slightly lower in the ADE (mean $=12.22 \mathrm{mg} / \mathrm{kg}$ ) compared to the ABE $($ mean $=18.19 \mathrm{mg} / \mathrm{kg})$ and the control $($ mean $=16.64 \mathrm{mg} / \mathrm{kg})$ profiles. Elsewhere Sodium has been noted as having elevated values in ADE (Glaser et al. 2001; McCann et al., 2001; Paz-Rivera and Putz, 2009; Smith, 1980; Woods et al., 2000). Iron and Aluminium are also depleted in the ADE compared to the control and ABE profile. Values are relatively stable throughout each profile with mean values of $\mathrm{Fe}, \mathrm{ADE}=8778 \mathrm{mg} / \mathrm{kg}, \mathrm{ABE}=43156 \mathrm{mg} / \mathrm{kg}$, and control $=40313 \mathrm{mg} / \mathrm{kg}$, and $\mathrm{Al}$ values of, $\mathrm{ADE}=25782 \mathrm{mg} / \mathrm{kg}, \mathrm{ABE}=72766 \mathrm{mg} / \mathrm{kg}$, and control $=71863 \mathrm{mg} / \mathrm{kg}$. These values perhaps reflect a leaching of the underlying soil closest to the lake, with no new inputs from anthropogenic activity. 


\subsection{Isotopes}

Isotopic analysis of bulk soil throughout the three profiles is characterised by a $C_{3}$ signal (Figure 6). $\mathrm{ADE}$ reports a mean $\delta^{13} \mathrm{C}$ of $-23.9 \%$, $\mathrm{ABE}$ has a mean of $-24.12 \%$, and the control has a mean of $25.79 \%$. The results suggest each location largely maintained canopy cover throughout its history. In all cases the upper stratigraphy $(0-15 \mathrm{~cm})$ shows a stronger $C_{3}$ signal (more negative). This likely reflects both an increase in post-abandonment arboreal cover, as well as reflecting changes in atmospheric carbon. Removing the top $15 \mathrm{~cm}$, the mean $\delta^{13} \mathrm{C}$ for $\mathrm{ADE}=-23.51, \mathrm{ABE}=-23.30$, and control $=-25.29$. The control location has a stronger $\mathrm{C}_{3}$ signal, suggesting there was a relative increase in $\mathrm{C}_{4}$ inputs into the onsite profiles. The $\mathrm{ABE}$ profile displays the highest $\mathrm{C}_{4}$ inputs, range $=$ $\delta 13 \mathrm{C}-21.72$ to -23.24 , mean $\delta 13 \mathrm{C}=-22.34$ between $75-35 \mathrm{~cm}$.

\subsection{Archaeobotany}

The three soil profiles (ADE, ABE, control) at Triunfo (Figure 7) are dominated by arboreal phytoliths, representing closed canopy forest (Iriarte et al. 2020). Arboreal phytoliths constitute $>50 \%$ phytoliths in both the ADE and ABE. In nearby regions of Bolivia, Dickau et al. (2013) have indicated that the minimum percentage of canopy cover phytoliths to represent a closed canopy (the sum of arboreal and palm phytoliths) is $35 \%$. The ADE has a mean of $76.9 \%$ arboreal phytoliths, ABE has a mean of $76.36 \%$, and the control has a mean of $95 \%$.

Anthropogenic soils begin at $95-100 \mathrm{~cm}$ in the ADE and 50-55 $\mathrm{cm}$ in the ABE. Both manioc and maize appear prior to the development of anthropogenic soil in both profiles. Manioc is present in the lowest samples in the $\mathrm{ADE}$ and $\mathrm{ABE}$ profiles at $105-110 \mathrm{~cm}$ and $70-75 \mathrm{~cm}$ depth, respectively. Maize first appears at $100-105 \mathrm{~cm}$ in the ADE and at $60-65 \mathrm{~cm}$ in the ABE. Both crops appear consistently throughout the ADE profiles. Out of 20 samples from ADE soil (excluding two pre-ADE formation samples), manioc is present in 12 samples and maize in 13. Both manioc and maize co-occur in nine samples. In the ABE profile crops are sparser, with a much lower ubiquity. From the eleven samples of $\mathrm{ABE}$ soil (excluding the four samples prior to $\mathrm{ABE}$ formation), manioc is present in six samples 
and maize appears in only three samples. Manioc phytoliths were also present in the control profile at $50-55 \mathrm{~cm}$ and $65-70 \mathrm{~cm}$.

Fragments of macrocharcoal (particles $/ \mathrm{cm}^{3}$ ) (Figure 7) were counted in each of the soil samples taken from the three soil test pits. In the ABE and ADE the charcoal fragments show an increase in the anthropogenic soils in comparison to the control. The average count in the ABE profile prior to anthrosol formation $(55-75 \mathrm{~cm})$ is 74 particles $/ \mathrm{cm}^{3}$, rising to 101 particles $/ \mathrm{cm}^{3}$ in the anthrosol. The pre-anthrosol samples $(100-110 \mathrm{~cm})$ in the ADE have an average of 18 particles $/ \mathrm{cm}^{3}$, rising to an average of 122 particles $/ \mathrm{cm}^{3}$ in the anthropogenic samples. There is an average of 55 charcoal particles $/ \mathrm{cm}^{3}$ in the control profile.

\section{Discussion}

\subsection{Soil Characteristics}

Soil chemistry shows distinct differences between ADE and ABE, largely in line with other studies in the Amazon (Paz-Rivera and Putz, 2009; Sombroek, 1966; Woods and McCann, 1999).

Anthropogenic soil is enriched in comparison to the control profile, with the ADE concentrations of P, $\mathrm{Ca}, \mathrm{Mg}, \mathrm{K}$, and $\mathrm{Zn}$, many times that of both the $\mathrm{ABE}$ and the control. While $\mathrm{ABE}$ is enriched in comparison to the control, actual values and the rate of increase is far lower than that of the ADE. The results confirm two distinct, concurrent processes were in effect in the creation of the two broad soil types, highlighting the need to assess both soil types within subsistence discussions. The higher concentration of organic matter in the $\mathrm{ABE}$ compared to the $\mathrm{ADE}$, coupled with lower concentrations of elements such as $\mathrm{P}, \mathrm{Ca}$, and $\mathrm{Mg}$, are consistent with the hypothesis that $\mathrm{ADE}$ incorporates domestic waste, while $\mathrm{ABE}$ results from long-term soil enrichment through activities such as burning and mulching (e.g., Arroyo-Kalin, 2010; Costa et al., 2013; Schmidt, 2013; Woods and McCann, 1999).

The phytolith results when combined with the geochemistry and isotopes further build a picture of spatially organised resource management, consumption and discard. Phytoliths provide a highly localised signal $\left(<2 \mathrm{~m}^{2}\right)$, as such, each profile represents in situ deposition from the plant's location of 
growth or discard. The phytolith and isotopic results characterise the three locations as maintaining canopy cover. The control shows $95 \%$ arboreal phytoliths, representing a closed-canopy forest throughout its ca. 2200-year history. There are increased grass inputs in the ADE and ABE locations, relative to the control, which reflects on site small clearances for habitation and crop cultivation, whereas the offsite forest was left intact (potential change in composition and enrichment of species is at present undetermined). The presence of crop phytoliths of maize (16/21 samples) and manioc (14/21 samples) in the ADE soil profile, complimented by the high values of Total $\mathrm{P}, \mathrm{Ca}$, and $\mathrm{Mg}$, is reflective of a concentrated accumulation of waste from food production and consumption. The lower ubiquity of crop phytoliths through the ABE profile (maize in 5/15 samples and manioc in 8/15 samples), coupled with the geochemistry that supports soil management practices and a higher proportion of $\mathrm{C}_{4}$ inputs, is representative of patches of crop cultivation. The absence of maize and manioc crop phytoliths in five samples from the ABE potentially reflects fallow periods. Despite the higher ubiquity of maize in the ADE compared to the $\mathrm{ABE}$, the lower contribution of $\mathrm{C}_{4}$ inputs suggests maize cultivation was not a major contributor to ADE soil formation, whereas the presence of maize phytoliths in the pre-anthropogenic depths of the ABE, likely reflect the location of cultivation, with substantial $\mathrm{C}_{4}$ inputs into soil formation. The integrated archaeobotanical, isotopic and geochemical data further emphasis the distinct activities associated with each soil type as part of overall settlement organisation.

As expected for domestic midden material including food production fires, the highest amount of soil charcoal is in the ADE. The high charcoal counts in the ABE (average $=101$ particles $/ \mathrm{cm}^{3}$ ) compared to the control $\left(\right.$ average $=55$ particles $\left./ \mathrm{cm}^{3}\right)$, demonstrates that fire was used in the crop cultivation areas, likely to clear patches, control weeds, and release nitrogen. Interestingly, the pre-anthrosol levels of the ABE show a relatively high charcoal count $\left(\right.$ average $=74$ particles $\left./ \mathrm{cm}^{3}\right)$ in comparison to the pre-anthrosol ADE profile (average $=18$ particles $/ \mathrm{cm}^{3}$ ) and across the control profile (average $=$ 55 particles $/ \mathrm{cm}^{3}$ ). Manioc and maize phytoliths are present in these early samples, suggesting the use of fire in land clearance for the initial crop cultivation, but this fire alone did not lead to the creation of $\mathrm{ABE}$ soils. 


\subsection{Soil Distribution}

Anthropogenic soils at Triunfo and Versalles demonstrate a spatial heterogeneity of ADE systems that reveal different approaches to settlement organisation and resource management. Patches of ADE at Versalles are separated by ABE buffers within the site boundary. Each homestead is surrounded by managed forest and agricultural plots. In contrast, all settlement activity was concentrated toward the lake at Triunfo, with forest management and agricultural activity separated from the habitation zone. Closer scrutiny of soil distribution and the distinction between ADE and ABE can thus be a useful line of evidence for understanding internal settlement patterns and resource management.

Both Triunfo and Versalles are located adjacent to water bodies. Intra-site distribution of soils further reveals the importance of water access. In both cases, domestic areas, represented by ADE, are in close proximity to the water. Although the Versalles distribution is more disperse, the settlement is elongated parallel to the river, while Triunfo concentrates ADE toward the lakeshore. While perhaps unsurprising that ease of access to permanent water influenced settlement organisation, direct evidence can be difficult to detect in sites with perishable architecture. Across Amazonia, ADE systems have predominately been found in strategically advantageous topographic positions on nonflooded lands (terra firme) (Kern et al., 2003), including plateaus and terraces overlooking rivers and streams (Denevan, 1996; Heckenberger et al., 2008; Kern et al., 2003; Levis et al.; 2014; Schaan, 2012; Stenborg et al., 2012). However, mounting evidence also shows the presence of ADE sites in interfluvial areas (de Souza, 2018; Franco-Moraes, 2019; Gonda, 2018; Heckenberger et al., 2008; Levis et al., 2012, 2017; Paz-Rivera and Putz, 2009; Schaan, 2012), highlighting the need for more research into the broad distribution of anthrosols in conjunction with intra-site patterning of ADE and ABE.

Although scant, existing reports documenting the size of both $\mathrm{ADE}$ and $\mathrm{ABE}$ show a range in spatial extent. In Para State, Brazil, Woods (2009) reports a 200 ha ADE with a surrounding ABE covering 1000 ha at Belterra, while Costa et al. (2013) document a smaller complex of two ADEs, measuring 
28 and 29 ha, surrounded by 300 ha of ABE at Juruti. The Oitavo Bec site (Woods and McCann, 1999), also in Para, is more similar to the Versalles distribution, with ADE zones embedded within 120 ha of ABE. Along the Madeira River, Brazil, multiple modern communities continue to grow crops on ADE sites, ranging in size from 14 to 50 ha (Fraser 2010; Fraser et al., 2009). While these measurements do not discriminate ABE from ADE, Fraser et al. (2009) do document the smallest ADE site, Agau Azul, consisting of 4 ha of ADE surrounded by 10 ha of ABE. A similarly smaller ADE complex is recorded in the Colombian Amazon, on the Araracuara Plateau, where 20 ha of ABE surround 6 ha of ADE (Myers, 2004). Paz-Rivera and Putz (2009) undertook a systematic survey of anthropogenic soils at La Chonta, Bolivia. In an area of 216 ha, they encountered nine patches of $\mathrm{ADE}$ and three patches of $\mathrm{ABE}$. ADE patches varied in size and shape between 0.3 to 10 ha. Specific areas within the ADE had higher concentrations of charcoal and ceramics, which likely reflect the location of kitchen middens. ABE patches surrounded the ADE, covering $0.3-1.0$ ha. The La Chonta example stands out in that the ABE is relatively small compared to the ADE, unlike other reported contexts in which the surrounding $\mathrm{ABE}$ is far larger than the associated ADE. The lack of detailed studies of $\mathrm{ABE}$ limits conclusive discussion, but the variety of results do demonstrate the variability of these non-standardised systems.

Spatial heterogeneity is further complicated by the temporal dimension. Population growth and decline, changing land use patterns, repurposed resources, fallow periods, and so forth, are beyond the resolution of most data sets. Although, the test pitting undertaken does provide a degree of relative chronology, a far more intensive and extensive archaeobotanical and geochemical testing strategy is required to elucidate more nuanced temporal changes to community settlement and resource management through time.

\subsection{Subsistence Practices}

The identification of a polyculture agroforestry practice (Maezumi et al., 2018), suggests ABE locations were composed of managed forest, orchards and small-scale crop plantations. Analysis of ABE at the Lago Grande site conducted by Arroyo-Kalin (2010) identifies probable management 
practices involving near-surface, in-situ burning of organic matter and scraping, raking or churning of cultivation soils. Elevated levels of magnetic susceptibility of ABEs indicates that iron in the soil became magnetised through in situ heating, suggesting near-surface burning of organic matter (Arroyo-Kalin, 2014) and Costa et al. (2013) show that ABE locations exhibit signs of successive burning of organic matter and transformation of minerals (maghemite to goethite). Mora (2003) notes that brown anthrosols can be present within settlement areas and ethnographic data from the Xingu document a mosaic of soils across plazas, houses, and domestic work and discard locations (Hecht, 2003; Heckenberger et al., 1999). Further investigations on settlement organisation found a relationship between midden locations and ADE sites in Central Amazon, Upper Xingu, and eastern Amazon, indicating a strong relationship between anthropogenic soil formation and human activity (Schmidt et al., 2014). Arroyo-Kalin (2014) suggests there are different types of ABE, including areas within settlements with less overall enrichment and areas beyond settlements where material signatures are consistent with reconstructed pre-Columbian practices of cultivation. The presence of post holes, distinct occupation surfaces and a cached ceramic in an ABE context at Versalles (T62) corroborates these interpretations suggesting non-agricultural activity for some ABE locations.

A nuance that requires further exploration, but cannot be answered with the data presented here, is whether and to what degree ADEs were used in food production as home gardens. The dark ADE are what are most sought after by modern farmers for their elevated, and persistent fertility (e.g. see Woods and McCann, 1999 for examples). However, the general model suggests ancient food production was focused in the $\mathrm{ABE}$, with the increased fertility of the $\mathrm{ADE}$ an unintentional byproduct of domestic waste. Home gardens can be difficult to detect archaeologically, but there are numerous ethnographic examples of herbs, fruiting trees, and small crop patches being tended within the domestic sphere on ADE. The modern Versalles village utilises the legacy mosaic of ADE and $\mathrm{ABE}$ patches for both home-garden and more intensive crop cultivation. Anthropological research conducted with the community assisted the documentation of cultural and environmental resources of the village (Diagnóstico y plan de la Comunidad de Versalles, 2019), including the presence and use of anthrosols for subsistence, and resulted in the publishing of bilingual websites 
(https://versallescommunity.wordpress.com/, https://comunidadversalles.wordpress.com/) celebrating the cultural and environmental heritage of the community. The domestic space of each household includes a variety of edible herbs, small crop patches (such as manioc) and fruiting trees that also serve as shade trees. Many of these are deliberately grown on ADE patches with clear knowledge of the increased fertility benefits. Larger agricultural units that are separated from the household on the edges of the community are also deliberately located on ADE. Ethnographic and ethnobotanical works show that traditional and indigenous communities across the Amazon take advantage of ADE for cultivation of nutrient demanding crops, such as maize, beans, and papaya (Balée, 2013; German, 2003; Hiraoka et al., 2004; Schmidt and Heckenberger, 2009; Woods and McCann, 1999) as well as productive varieties of manioc (e.g., Fraser, 2010). Although exceptions do exist, such as the cultural restrictions of the indigenous Tikuna of Colombia (Sanabria and Ricaurte, 2013), who refuse to cultivate ADE sites as these are ancient places owned by the ancestors. Exceptions aside, it is highly likely that many pre-Columbian communities exploited the heightened fertility of ADE (whether intentional in its creation or not) to supplement food production, including the management of edible plants within domestic space, such as the use of home gardens. Systematic spatial analysis of ADE and $\mathrm{ABE}$, combining a suite of archaeobotanical, micromorphological and chemical analyses specifically to assess the range of potential food production is required.

\subsection{Remote Sensing and the Pre-Columbian Legacy on Modern Forests}

The striking overlap between modern vegetation and the anthropogenic soils as visible in remote sensing imagery indicate a legacy of human impact on forest composition. Alongside an enrichment in edible species, ADE sites are characterised by lower canopy vegetation and a more closed understory. Recent research by Palace et al. (Palace et al., 2017) using satellite remote sensing also show that ADE sites have less green canopies, lower canopy water content, increased drought susceptibility, and lower biomass and tree height compared with randomly selected sites adjacent to the ADE soils. At Versalles and Triunfo, satellite imagery shows a distinct vegetation cover that corresponds to the distribution of ADE. Palms, mainly cusi (Attalea sp.) and to a lesser extent, 
chocolate, dominate vegetation cover in areas of ADE at Triunfo, while the Versalles site is has a wide variety of edible fruiting trees and palms still utilised by the modern village.

Forests on today's ADEs have a distinct species composition, exhibiting greater richness and a higher abundance of exotic, high-nutrient demanding, domesticated and edible plants in comparison to nonADE locations (Almeida de Oliveira, 2020; de souza et al. 2017; Junqueira et al., 2011; Levis et al., 2012; Lins, 2015; Maezumi et al., 2018; Odonne et al., 2019; Palace et al., 2017; Quintero-Vallejo, 2015; Santos et al., 2018). Interdisciplinary research has shown that millennial-scale polyculture agroforestry systems have an enduring legacy on the hyperdominance of edible plants in modern forests in the eastern Amazon (Maezumi et al., 2018). For example, botanical inventories carried out in riverine caboclo communities of the Middle Madeira by Junqueira et al. (Junqueira et al., 2011) have identified 11 indicator species, including three palms that figure prominently; caiaué (Elaeis oleifera), urucuri (Attalea cf. phalerata) and murumuru (Astrocaryum murumuru). In the eastern Amazon, Woods and McCann (1999) have repeatedly observed an enrichment of key edible species, including Brazil nut (Bertholletia excelsa), chocolate, cupuaçu (T. grandiflorum) and saumauma (Ceiba pentandra) growing on ADE sites. The correlation between satellite imagery and preColumbian settlement shows the potential of remote sensing for identifying archaeological sites and assessing long-term human impact on biodiversity.

\subsection{Fortification}

Despite differences in the intra-site distribution of $\mathrm{ADE}$ and $\mathrm{ABE}$, the enclosing of anthrosols at both Triunfo and Versalles mark the importance of these soil resources and food production. The remote sensing imagery confirm that anthrosols were not present outside of the bounded sites. The location of the zanjas at the edge of $\mathrm{ABE}$ strongly suggests a key function of the feature was to enclose and protect the cultivation areas with their enriched soil, crops, and modified arboreal composition. Multiple functions of zanjas have been proposed, with a combination of water management and fortification most likely. The presence of post holes within the zanja at Versalles suggests the ditch 
was combined with a palisade. Fortifications built around ADE sites have also been recorded in the Central Amazon during periods of increased conflict, hinting at the importance of the soils in community planning and suggesting competition for ADE soils and the need to defend those resources (de Paula Moraes and Neves, 2012). The construction of the double ring ditch at Triunfo certainly suggests a defensive function and shallow anthrosols are present in the interior plaza; however, these soils have not been analysed chemically nor archaeobotanically to understand their genesis or use. As such, at present we are unable to resolve exactly what was being fortified here and how this architectural feature related to other resources across the site.

The emergence of the ditched fortifications cal CE 1500 at Versalles must be understood within the broader context of cultural transformations along the southern rim of the Amazon during this time period (De Souza et al. 2019). South of the study area, zanjas in Bella Vista and Baures are dated cal CE 1300-1500 (Prümers and Jaimes Betancourt, 2014). Approximately $170 \mathrm{~km}$ to the west, zanjas have been surveyed in the Yacuma and Rapulo Rivers and were also dated to this time period (Walker, 2018). Ditched enclosures are also found in the state of Rondonia, across the Iténez River. Similar sites stretch as far as the Upper Xingu River to the east, where a network of fortified settlements connected by roads emerged cal CE 1300 (Heckenberger et al., 2008). In the intermediate area, in the headwaters of the Tapajós River, ditched enclosures associated with ADE are dated ca. cal CE 1400 (De Souza et al., 2018). The second construction phase of the Versalles zanja, with the addition of the palisade cal CE 1628-1803 indicate persisting need to fortify. The increasing concern for fortification around Laguna Versalles indicates that the communities were drawn into Amazon wide interactions and conflict.

\subsection{Summary}

Research at Versalles and Triunfo provide data on the distribution and composition of anthropogenic soils. Geochemistry and archaeobotany from ADE, ABE and control soil profiles from Triunfo characterise distinct processes in the creation of the two broad anthrosol types, supporting a polyculture agroforestry system that includes crop agriculture on enriched anthrosols within a largely 
closed canopy manged forest. Despite all anthropogenic soils being enclosed within a fortified landscape at both sites, soil test pits at Triunfo and Versalles reveal two different soil distribution patterns, demonstrating a heterogeneity in settlement organisation and resource management. The results provide insight into a subsistence system that defines much of pre-Columbian Amazonia and has a lasting impact on the structure and composition of the tropical forest.

\section{ACKNOWLEDGEMENTS}

Research was supported by the PAST (Pre-Columbian Amazon-Scale Transformations) European Research Council Consolidator Grant to J.I. (ERC_Cog616179). Research was conducted under permit authorization MDCyT-UDAM N ${ }^{\circ}$ 071/2017. The authors thank the three anonymous reviewers and journal editors for their insightful comments that have improved this manuscript.

\section{DATA SHARING}

The data that supports the findings of this study are available in the supplementary material of this article and upon request to the authors.

\section{CONFLICT OF INTEREST}

The authors confirm there are no conflicts of interest.

\section{REFERENCES}

Almeida de Oliveira, E., Marimon-Junior, B., Schwantes-Marimon, B., Iriarte, J., Morandi, P., Maezumi, S., Nogueira, D., Aragão, L.E.O., Brasil da Silva, I., \& Feldpausch, T. (2020). Legacy of Amazonian Dark Earth soils on forest structure and species composition. Global Ecology and Biogeography 00, 1-16.

Alves, D. (2017). Dark Earth plant management in the Lower Tapajós. PhD Dissertation, Department of Archaeology. University of Exeter, Exeter. 
Arroyo-Kalin, M. (2008). Steps towards an ecology of landscape: A geoarchaeological approach to the study of anthropogenic dark earths in the central Amazon region, Brazil (Doctoral dissertation, University of Cambridge).

Arroyo-Kalin, M. (2010). The Amazonian formative: crop domestication and anthropogenic soils. Diversity 2, 473-504.

Arroyo-Kalin, M. (2012). Slash-burn-and-churn: Landscape history and crop cultivation in pre Columbian Amazonia. Quaternary International 249, 4-18.

Arroyo-Kalin, M. (2014). The variability of Amazonian Dark Earths: comparing anthropogenic soils from three regions of the Amazonian biome. In Rostain, S. (eds) Antes de Orellana, Actas del 3er Encuentro Internacional de Arqueologia Amazonica, pp. 323-330.

Balée, W. (2013). Cultural Forests of the Amazon. A Historical Ecology of People and Their Landscapes. University of Alabama Press, Tuscaloosa.

Becker-Donner, E. (1956). Archäologische Funde am mittleren Guaporé (Brasilien). In Archiv für Völkerkunde, Band XI. Viena.

Blatrix, R., Roux, B., Béarez, P., Prestes-Carneiro, G., Amaya, M., Aramayo, J.L., Rodrigues, L., Lombardo, U., Iriarte, J., de Souza, J.G., Robinson, M., Bernard, C., Pouilly, M., Durécu, M., Huchzermeyer, C.F., Kalebe, M., Ovando, A., \& McKey, D. (2018). The unique functioning of a preColumbian Amazonian floodplain fishery. Scientific Reports 8 (1), 5998.

Brugger, S.O., Gobet, E., Van Leeuwen, J.F.N., Ledru, M., Colombaroli, D., Oscar van der Knaap, W., Lombardo, U., Escobar-Torrez, K., Finsinger, W., \& Rodrigues, L. (2016). Long-term man- 
environment interactions in the Bolivian Amazon: 8000 years of vegetation dynamics. Quaternary Science Reviews 132, 114-128.

Capriles, J.M, Lombardo, U., Maley, B., Zuna, C., Veit, H., \& Kennett, D.J. (2019). Persistent Early to Middle Holocene tropical foraging in southwestern Amazonia. Science advances 5 (4), 5449.

Carson, J.F., Whitney, B.S., Mayle, F.E., Iriarte, J., Prümers, H., Soto, J.D., \& Watling, J. (2014). Environmental impact of geometric earthwork construction in pre-Columbian Amazonia. Proceedings of the National Academy of Sciences 111 (29), 10497-10502.

Carson, J.F., Watling, J., Mayle, F., Whitney, B., Iriarte, J., Prümers, H., \& Soto, J.D. (2015). PreColumbian land use in the ring-ditch region of the Bolivian Amazon. The Holocene 25(8), 1285-1300.

Clement, C.R. (1999). 1492 and the loss of Amazonian crop genetic resources. II. Crop biogeography at contact. Economic Botany 53 (2), 203-216.

Clement, C.R., Rodrigues, D.P., Alves-Pereira, A., Santos Mühlen, G., de Cristo-Araújo, M., Moreira, P.A., Lins, J., \& Reis, V.M. (2016). Crop domestication in the upper Madeira River basin. Boletim do Museu Paraense Emílio Goeldi. Ciências Humanas 11 (1), 193-205.

Costa, J.A., da Costa, M.L., \& Kern, D.C. (2013). Analysis of the spatial distribution of geochemical signatures for the identification of prehistoric settlement patterns in ADE and TMA sites in the lower Amazon Basin. Journal of Archaeological Science 40, 2771-2782.

de Paula Moraes, C., \& Neves, E.G. (2012). O ano 1000: adensamento populacional, interação e conflito na Amazônia Central. Amazônica-Revista de Antropologia 4 (1), 122-148. 
de Souza, N.B., Junqueira, A.B., Struik, P.C., Stomph, T., \& Clement, C.R. (2017). The role of fertile anthropogenic soils in the conservation of native and exotic agrobiodiversity in Amazonian homegardens. Agroforestry Systems 1-12.

De Souza, J.G., Schaan, D.P., Robinson, M., Damasceno Barbosa, A., Aragão, L., Marimon Jr, B.H., Marimon, B.S., Silva, I.B., Khan, S.S., \& Nakahara, F.R. (2018). Pre-Columbian earth-builders settled along the entire southern rim of the Amazon. Nature Communications 9 (1), 1125.

De Souza, J.G., Robinson, M., Maezumi, S.Y., Capriles, J., Hoggarth, J., Lombardo, U., Novello, V., Apaestegui, J., Whitney, B., Urrego, D., Alves, D., Rostain, S., Power, M., Mayle, F., Cruz Jr. F., Hooghiemstra, H., \& Iriarte, J. (2019). Climate change and cultural resilience in late pre-Columbian Amazonia. Nature Ecology \& Evolution 3, 1007-1017.

Denevan, W.M. (1996). A bluff model of riverine settlement in prehistoric Amazonia. Annals Association of American Geographers 86, 654-681.

Dickau, R., Bruno, M.C., Iriarte, J., Prümers, H., Jaimes Betancourt, C., Holst, I., \& Mayle, F.E. (2012). Diversity of cultivars and other plant resources used at habitation sites in the Llanos de Mojos, Beni, Bolivia: evidence from macrobotanical remains, starch grains, and phytoliths. Journal of Archaeological Science 39, 357-370.

Dickau, R., Whitney, B.S., Iriarte, J., Mayle, F.E., Soto, J.D., Metcalfe, P., Street-Perrott, F.A., Loader, N.J., Ficken, K.J., Killeen, T.J. (2013). Differentiation of neotropical ecosystems by modern soil phytolith assemblages and its implications for palaeoenvironmental and archaeological reconstructions. Review of Palaeobotany and Palynology 193, 15-37. 
Dümig, A., Schad, P., Rumpel, C., Dignac, M.F., Kögel-Knabner, I. (2008). Araucaria forest expansion on grassland in the southern Brazilian highlands as revealed by $14 \mathrm{C}$ and $\delta 13 \mathrm{C}$ studies. Geoderma 145(1), 143-157.

Eder, F.J. (1985 [1772]). Breve Descripción de las Reducciones de Mojos. Cochabamba: Historia Boliviana.

Erickson, C.L. (2000). An artificial landscape-scale fishery in the Bolivian Amazon. Nature 408 (6809), 190-193.

Erickson, C. (2004). Historical ecology and future explorations, In Lehmann, J., Kern, D.C., Glaser, B., Woods, W.I. (Eds.), Amazonian Dark Earths: Origins, Properties, Management. Springer, New York, pp. 455-500.

Erickson, C.L. (2008). Amazonia: the historical ecology of a domesticated landscape, In Silverman, H., Isbell, W. (Eds.), The Handbook of South American Archaeology. Springer, New York, pp. 157183.

Erickson, C.L. (2009). Agency, causeways, canals and the landscapes of everyday life in the Bolivian Amazon. In J.E. Snead, C. Erickson and J.A. Darling (eds) Landscapes of Movement: Trails, Paths, and Roads in Anthropological Perspective. Philadelphia: University of Pennsylvania Museum of Archaeology and Anthropology, 204-231.

Erickson, C.L. (2010). The transformation of environment into landscape: The historical ecology of monumental earthwork construction in the Bolivian Amazon. Diversity 2(4), 618-652.

Erickson, C.L., Alvarez, P., \& Calla, S. (2008). Zanjas Circundantes: Obras Monumentales de Tierra de Baures en la Amazonia Boliviana. Informe de trabajo de campo de la temporada 2007. 
Franco-Moraes, J., Baniwa, A.F., Costa, F.R., Lima, H.P., Clement, C.R., \& Shepard Jr, G.H. (2019). Historical landscape domestication in ancestral forests with nutrient-poor soils in northwestern Amazonia. Forest Ecology and Management 446, 317-330.

Fraser, J.A. (2010). Caboclo horticulture and Amazonian dark earths along the middle Madeira River, Brazil. Human Ecology 38, 651-662.

Fraser, J., Cardoso, T., Junqueira, A., Falcão, N.P.S., Clement, C.R. (2009). Historical ecology and dark earths in whitewater and blackwater landscapes: comparing the Middle Madeira and Lower Negro rivers, In Woods, W.I., Teixeira, W.G., Lehmann, J., Steiner, C., WinklerPrins, A.M.G.A., Rebellato, L. (Eds.), Amazonian Dark Earths: Wim Sombroek's vision. Springer, Berling, pp. 229-264.

Fraser, J., Teixeira, W., Falcão, N., Woods, W., Lehmann, J., Junqueira, A.B. (2011). Anthropogenic soils in the Central Amazon: from categories to a continuum. Area 43, 264-273.

German, L. (2003). Ethnoscientific understandings of Amazonian dark earths, In: Lehmann, J., Kern, D.C., Glaser, B., Woods, W.I. (Eds.), Amazonian Dark Earths. Springer, pp. 179-201.

Glaser, B. (2007). Prehistorically modified soils of central Amazonia: a model for sustainable agriculture in the twenty-first century. Philosophical Transactions of the Royal Society B: Biological Sciences 362 (1478), 187-196.

Glaser, B., \& Birk, J.J. (2012). State of the scientific knowledge on properties and genesis of Anthropogenic Dark Earths in Central Amazonia 'terra preta de Índio'. Geochimica et Cosmochimica Acta 82, 39-51. 
Glaser, B., Haumaier, L., Guggenberger, G., \& Zech, W. (2001). The 'Terra Preta' phenomenon: a model for sustainable agriculture in the humid tropics. Naturwissenschaften 88, 37-41.

Gonda, R. (2018). Pre-Columbian land use and its modern legacy in the Purus-Madeira Interfluve, Central Amazonia. PhD Dissertation, Department of Archaeology, University of Exeter, Exeter.

Hastik, R., Geitner, C., \& Neuburger, M. (2013). Amazonian Dark Earths in Bolivia? A soil study of anthropogenic ring ditches near Baures (Eastern Llanos de Mojos). Erdkunde, 137-149.

Hecht, S.B. (2003). Indigenous soil management and the creation of terra mulata and terra preta in the Amazon Basin, In Lehmann, J., Kern, D., Glaser, B., Woods, W.I. (Eds.), Amazonian Dark Earths: Origin Properties and Management. Springer, Dordrecht, pp. 355-372.

Heckenberger, M., \& Neves, E.G. (2009). Amazonian archaeology. Annual Review of Anthropology $38,251-266$.

Heckenberger, M., Petersen, J.B., \& Neves, E.G. (1999). Village size and permanence in Amazonia: two archaeological examples from Brazil. Latin American Antiquity, 353-376.

Heckenberger, M., Russell, J.C., Fausto, C., Toney, J.R., Schmidt, M.J., Pereira, E., Franchetto, B., \& Kuikuro, A. (2008). Pre-Columbian urbanism, anthropogenic landscapes, and the future of the Amazon. Science 321 (5893), 1214.

Hilbert, L., Neves, E.G., Pugliese, F., Whitney, B.S., Shock, M., Veasey, E., Zimpel, C.A., \& Iriarte, J. (2017). Evidence for mid-Holocene rice domestication in the Americas. Nature Ecology \& Evolution 1 (11), 1693-1698. 
Hiraoka, M., Yamamoto, S., Matsumoto, E., Nakamura, S., Falesi, I., Ronaldo, A., Baena, C. (2004). Contemporary use and management of Amazonian Dark Earths, In: Lehmann, J., Kern, D., Glaser, B., Woods, W.I. (Eds.), Amazonian Dark Earths: Origins, Properties, Management. Springer, pp. 387406.

Iriarte, J., Elliott, S., Maezumi, S.Y., Alves, D., Gonda, R., Robinson, M., de Souza, J.G., Watling, J., Handley, J. (2020). The origins of Amazonian landscapes: plant cultivation, domestication and the spread of food production in tropical South America. Quaternary Science Reviews 248, 106582.

Jaimes Betancourt, C. (2011). La cerámica de los afluentes del Guaporé en la colección de Erland von Nordenskiöld. Zeitschrift für Archäologie Außereuropäischer Kulturen 4, 311-340.

Jaimes Betancourt, C. (2016). Dos fases cerámicas de la cronología ocupacional de las zanjas de la provincia Iténez -Beni, Bolivia. In C. Barreto, H. Lima and C. Jaimes Betancourt (eds) Cerâmicas Arqueológicas da Amazônia: rumo a uma nova síntesis. Belem: IPHAN: Ministério da Cultura und Museo Paraense Emílio Goeldi.

Junqueira, A.B., Shepard Jr, G.H., \& Clement, C.R. (2011). Secondary forests on anthropogenic soils of the Middle Madeira River: Valuation, local knowledge, and landscape domestication in Brazilian Amazonia. Economic Botany 65 (1), 85-99.

Kern, D.C., Kampf, N. (1989). Antigos assentamentos indígenas na formação de solos com terra preta arqueológica na região de Oriximiná, Pará. Revista Brasileira de Ciência do Solo 13, 219-225.

Kern, D.C., D’aquino, G., Rodrigues, T.E., Frazao, F.J.L., Sombroek, W., Myers, T.P., \& Neves, E.G. (2003). Distribution of Amazonian dark earths in the Brazilian Amazon, In Lehmann, J., Kern, D., Glaser, B., Woods, W.I. (Eds.), Amazonian Dark Earths. Springer, Dordrecht, pp. 51-75. 
Kern, D.C., Lima, H.P., da Costa, J.A., de Lima, H.V., Browne Ribeiro, A., Moraes, B.M., \& Kämpf, N. (2017). Terras pretas: Approaches to formation processes in a new paradigm. Geoarchaeology 32, 694-706.

Langstroth, R. 2012. Biogeography of the Llanos de Moxos: natural and anthropogenic determinants. Geographica Helvetica 66 (3), 183-192.

Lehmann, J., da Silva Jr, J.P., Steiner, C., Nehls, T., Zech, W., \& Glaser, B. (2003). Nutrient availability and leaching in an archaeological Anthrosol and a Ferralsol of the Central Amazon basin: fertilizer, manure and charcoal amendments. Plant and Soil 249, 343-357.

Lehmann, J., Kern, D.C., Glaser, B., Woods, W.I. (2004). Amazonian Dark Earths: Origin, Properties, Management. Springer Dortdrech.

Levis, C., de Souza, P.F., Schietti, J., Emilio, T., da Veiga Pinto, J.L.P., Clement, C.R., \& Costa, F.R.C. (2012). Historical Human Footprint on Modern Tree Species Composition in the PurusMadeira Interfluve, Central Amazonia. PLoS One 7 (11), e48559.

Levis, C., Costa, F.R.C., Bongers, F., Peña-Claros, M., Clement, C.R., Junqueira, A.B., Neves, E.G., Tamanaha, E.K., Figueiredo, F.O.G., \& Salomão, R.P. (2017). Persistent effects of pre-Columbian plant domestication on Amazonian forest composition. Science 355 (6328), 925-931.

Levis, C., Silva, M., Silva, M., Moraes, C.P., Neves, E., Tamanaha, E., Flores, B., Clement, C.R., (2014). What do we know about the distribution of Amazonian Dark Earth along tributary rivers in Central Amazonia? In Rostain, S. (Ed.), Antes de Orellana-Actas del 3er Encuentro Internacional de Arqueología Amazónica. Instituto Frances de Estudios Andinos, Quito, pp. 305-312. 
Lins, J., Lima, H.P., Baccaro, F.B., Kinupp, V.F., Shepard Jr, G.H., \& Clement, C.R. (2015). PreColumbian floristic legacies in modern homegardens of Central Amazonia. PLoS One 10 (6), e0127067.

Lombardo, U., Canal-Beeby, E., \& Veit, H. (2011). Eco-archeological regions in the Bolivian Amazon. An overview of pre-Columbian earthworks linking them to their environmental settings. Geographica Helvetica 66 (3), 173-182.

Lombardo, U., Denier, S., \& Veit, H. (2015). Soil properties and pre-Columbian settlement patterns in the Monumental Mounds Region of the Llanos de Moxos, Bolivian Amazon. Soil 1 (1), 65-81.

Lombardo, U., Iriarte, J., Hilbert, L., Ruiz-Pérez, J., Capriles, J.M., Veit, H. (2020). Early Holocene crop cultivation and landscape modification in Amazonia. Nature 581, 190-193.

Maezumi, S.Y., Alves, D., Robinson, M., De Souza, J.G., Levis, C., Barnett, R.L., De Oliveira, E., Urrego, D., Schaan, D., \& Iriarte, J. (2018). The legacy of 4,500 years of polyculture agroforestry in the eastern Amazon. Nature Plants 4, 540-547.

Mayle, F.E., Langstroth, R.P., Fisher, R.A., \& Meir, P. (2007). Long-term forest-savannah dynamics in the Bolivian Amazon: implications for conservation. Philosophical Transactions of the Royal Society B: Biological Sciences 362 (1478), 291.

McCann, J.M., Woods, W.I. and Meyer, D.W. (2001). Anthrosols in Amazonia: Interpreting the Amerindian Legacy. In Rees, Ball, Campbell and Watson (eds) Sustainable management of soil organic matter, CABI Publishing, New York, pp.180-189. 
McMichael, C.H., Palace, M.W., Bush, M.B., Braswell, B., Hagen, S., Neves, E.G., Silman, M.R.,

Tamanaha, E.K. \& Czarnecki, C. (2014). Predicting pre-Columbian anthropogenic soils in Amazonia. Proceedings of the Royal Society B: Biological Sciences, 281(1777), 20132475.

Mora, S. (2003). Early Inhabitants of the Amazonian Tropical Rain Forest: a Study of Humans and Environmental Dynamics. University of Pittsburgh Latin American Archaeology Reports, Pittsburgh.

Mora, S., Herrera, L.F., Cavalier, I., Rodríguez, C. (1991). Cultivars, anthropic soils, and stability: a preliminary report of archaeological research in Araracuara, Colombian Amazonia. Latin American Archaeology Reports 2. University of Pittsburgh.

Myers, T.P. (2004). Dark Earth in the Upper Amazon, In Glaser, B., Woods, W.I. (Eds.), Amazonian Dark Earths: Explorations in space and time. Springer, Berlin, pp. 67-94.

Neumann, K., Strömberg, C., Ball T., Albert, R., Vrydaghs, L., Cummings, L. (2019). International Committee for Phytolith Taxonomy (ICPT): International code for phytolith nomenclature (ICPN), 2.0. Annals of Botany, 124(2), 189-199

Nordenskiöld, E. (1923). Indianer und Weisse in Nordostbolivien. Stuttgart.

Nordenskiöld, E. (1924). Forschungen und Abenteuer in Südamerika. Stuttgart.

Odonne, G., Van den Bel, M., Burst, M., Brunaux, O., Bruno, M., Dambrine, E., Davy, D., Desprez, M., Engel, J., \& Ferry, B. (2019). Long-term influence of early human occupations on current forests of the Guiana Shield. Ecology 100, e02806.

Olson, D.M., Dinerstein, E., Wikramanayake, E.D., Burgess, N.D., Powell, G.V.N., Underwood, E.C., D'amico, J.A., Itoua, I., Strand, H.E., \& Morrison, J.C. (2001). Terrestrial Ecoregions of the World: A 
New Map of Life on Earth a new global map of terrestrial ecoregions provides an innovative tool for conserving biodiversity. BioScience 51 (11), 933-938.

Palace, M.W., McMichael, C.N.H., Braswell, B.H., Hagen, S.C., Bush, M.B., Neves, E., Tamanaha, E., Herrick, C., \& Frolking, S. (2017). Ancient Amazonian populations left lasting impacts on forest structure. Ecosphere 8 (12).

Paz-Rivera, C., \& Putz, F.E. (2009). Anthropogenic soils and tree distributions in a lowland forest in Bolivia. Biotropica 41, 665-675.

Piperno, D.R., \& Pearsall, D.M. (1998). The Origins of Agriculture in the Lowland Neotropics. San Diego: Academic Press.

Prumers, H. (2014). Sitios prehispánicos con zanjas en Bella Vista, Provincia Iténez, Bolivia, Amazonía. In S. Rostain (ed) Memorias del 3er Encuentro Internacional de Arqueología Amazónica, Quito: IFEA, 73-89.

Prümers, H., \& Jaimes Betancourt, C. (2014). 100 años de investigación arqueológica en los Llanos de Mojos. Arqueoantropológicas 4, 11-53.

Prümers, H., \& Jaimes Betancourt., C. (2017). Die Phase Equijebe in Jasiaquiri und Urnengräber am Guaporé. Zeitschrift für Archäologie Außereuropäischer Kulturen, 357-372.

Prümers, H., Jaimes Betancourt, C., \& Plaza Martinez, R. (2006). Algunas tumbas prehispánicas de Bella Vista, Prov. Iténez, Bolivia. Zeitschrift für Archäologie Außereuropäischer Kulturen 1, 251284. 
Quintero-Vallejo, E., Klomberg, Y., Bongers, F., Poorter, L., Toledo, M., \& Peña-Claros, M. (2015).

Amazonian dark earth shapes the understory plant community in a Bolivian forest. Biotropica 47, $152-161$

Sanabria, C.T., Ricaurte, J.A.C. (2013). Uso de los suelos antropogénicos amazónicos: Comparación entre comunidades Caboclas e indígenas Tikunas. Gestion y Ambiente 16, 5-17.

Santos, M., Disney, M., \& Chave, J. (2018). Detecting Human Presence and Influence on Neotropical Forests with Remote Sensing. Remote Sensing 10 (10), 1593.

Schaan, D.P. (2012). Sacred Geographies of Ancient Amazonia: Historical Ecology of Social Complexity. Left Coast Press, Walnut Creek.

Schmidt, M. (2013). Amazonian Dark Earths: pathways to sustainable development in tropical rainforests? Boletim do Museu Paraense Emílio Goeldi. Ciencias Humanas, 8, 11-38.

Schmidt, M.J., Heckenberger, M.J. (2009). Amerindian anthrosols: Amazonian Dark Earth formation in the Upper Xingu, In: Woods, W.I., Teixeira, W.G., Lehmann, J., Steiner, C., WinklerPrins, A.M.G.A., Rebellato, L. (Eds.), Amazonian Dark Earths: Wim Sombroek's Vision. Springer, Berlin, pp. 163-191.

Schmidt, M.J., Rapp Py-Daniel, A., De Paula Moraes, C., Valle, R.B.M., Caromano, C.F., Texeira, W.G., Barbosa, C.A., Fonseca, J.A., Magalhães, M.P., Silva Do Carmo Santos, D., Da Silva E Silva, R., Guapindaia, V.L., Moraes, B., Lima, H. P., Neves, E.G. \& Heckenberger, M.J. (2014). Dark earths and the human built landscape in Amazonia: a widespread pattern of anthrosol formation. Journal of Archaeological Science 42, 152-165. 
Sombroek, W. (1966). Amazon Soils: A Reconnaisance of the Soils of the Brazilian Amazon Region. Wageningen: Center for Agricultural Pubilications and Documentation.

Stenborg, P., Schaan, D.P., Lima, M.A. (2012). Precolumbian land use and settlement pattern in the Santarém region, lower Amazon. Amazônica-Revista de Antropologia, Belém 4, 222-250.

Sombroek, W., Kern, D., Rodrigues, T., Cravo, M.d.S., Jarbas, T.C., Woods, W., Glaser, B. (2002). Terra Preta and Terra Mulata: pre-Columbian Amazon kitchen middens and agricultural fields, their sustainability and their replication. 17th World Congress of Soil Science. Bangkok, Thailand.

Stenborg, P. (2016). Archaeological research at hinterland sites on the Belterra Plateau, Pará, In:

Stenborg, P. (Ed.), Beyond Waters. Archaeology and Environmental History of the Amazonian Inland. University of Gothenburg, Gothenburg, pp. 113-126.

Teixeira, W.G.T., Kern, D.C., Madari, B.E., Lima, N.H., \& Woods, W.I. (2010). As Terras Pretas de Indio da Amazônia: Sua Caracterização e Uso deste Conhecimento na Criação de Novas Areas. Embrapa Amazônia Ocidental, Manaus.

Troufflard, J., Alves, D.T. (2019). Uma abordagem interdisciplinar do sítio arqueológico Cedro, baixo Amazonas. Boletim do Museu Paraense Emílio Goeldi. Ciências Humanas 14, 553-580.

Walker, J.H. (2008). The Llanos de Mojos. In H. Silverman and W. Isbell (eds) Handbook of South American Archaeology, New York: Springer, 927-939.

Walker, J.H. (2018). Island, River and Field: Landscape Archaeology in the Llanos de Mojos. University of New Mexico Press. Albuquerque. 
Watling, J., Shock, M.P., Mongeló, G.Z., Almeida, F.O., Kater, T., De Oliveira, P. E, \& Neves, E.G. (2018). Direct archaeological evidence for Southwestern Amazonia as an early plant domestication and food production centre. PLoS One 13 (7), e0199868.

Woods, W.I., \& McCann, J.M. (1999). The anthropogenic origin and persistence of Amazonian dark earths. Yearbook. Conference of Latin Americanist Geographers. University of Texas Press, Austin, pp. 7-14.

Woods, W.I., Teixeira, W.G., Lehmann, J., Steiner, C., Winkler Prins, A.M.G.A., \& Rebellato, L. (2009). Amazonian Dark Earths: Wim Sombroek's Vision. Berlin: Springer.

Woods, W. (2009). Os solos e as ciências humanas: Interpretação do passado, In Teixeira, W.G., Kern, D.C., Madari, B.E., Lima, H., Woods, W.I. (Eds.), As Terras Pretas de Índio da Amazônia: sua caracterização e uso deste conhecimento na criação de novas áreas. Embrapa Amazonia Ocidental, Manaus, pp. 62-71.

Woods, W.I., McCann, J.M., \& Meyer, D.W. (2000). Amazonian Dark Earth analysis: state of knowledge and directions for future research, Papers and Proceedings of the Applied Geography Conferences, 114-121.

\section{Figure captions}

Figure 1. Regional map, showing the location of the study area and the distribution of ADE and ditched enclosure sites across Amazonia. The star marks the location of the study area, which is detailed in the inset. Inset numbers refer to: 1) Versalles site, 2) Versalles zanja, 3) Escondido site, 4) likely pre-Columbian feature that requires further exploration, 5) Triunfo zanja and ring ditch, 6) Triunfo site. 
Figure 2. Landsat imagery showing distinct patches of vegetation corresponding to the distribution of anthropogenic soils at Triunfo and Versalles. Labelled sites: 1) Versalles, 2) Escondido, 3) Noria, and 4) Triunfo.

Figure 3. Profile and photo of zanja excavation at Versalles, showing the two construction episodes and the location of the post hole. Note the two post holes visible in the photo.

Figure 4. Map showing the location, depth and colour of soil profiles at Versalles. The soil colour on the map represents the colour of the top $10 \mathrm{~cm}$ of soil. The displayed profiles show the depths and colour changes of the soil. All colours are shown using RGB values of the recorded Munsell values of the soil. The zanja and T62 excavation locations are marked.

Figure 5. Map showing the location, depth, and colour of soil profiles at Triunfo. The three soil test pit locations (ADE, ABE, Control) are marked. All colours are shown using RGB values of the recorded Munsell values of the soil.

Figure 6. Graphs of soil isotopes and select geochemistry results. See SI for complete dataset.

Figure 7. Archaeobotanical summary graphs of canopy, herb, and crop (maize and manioc) phytoliths, macrocharcoal counts, soil colour, and radiocarbon dates. P1 displays results from the ADE, P2 the $\mathrm{ABE}$, and $\mathrm{P} 3$ the Control profile. Crops are displayed as presence/absence (not counts). Arboreal includes palm and tree phytolith morphotypes. 